\title{
Guide to Identifying and Controlling Postharvest Tomato Diseases in Florida ${ }^{1}$
}

\author{
Jerry A. Bartz, Gary E. Vallad, and Steven A. Sargent ${ }^{2}$
}

Florida tomato production is often challenged by an array of plant diseases that are favored by moist weather (Jones et al. 2014). Conditions that promote plant diseases also favor the development of fruit rots, both in the field and during handling and shipping.

Fruit rots are generally caused by opportunistic pathogens that normally live on plant debris. However, these opportunists can infect tissues that are wounded and/or exposed (no protective surface) or diseased. These microorganisms are ubiquitous (found everywhere) in the natural environment, in part because they are good saprophytes. Mechanical injuries on the fruit surface (e.g., cuts, punctures) that occur during harvest and handling are a frequent site for decay development. Under certain conditions, decay pathogens can internalize (enter tissues beneath the fruit surface) and cause lesions that begin inside the fruit. Internal bruises may occur during harvest, and certain fungi can colonize the damaged tissues, producing an internal lesion.

Fruits and vegetables vary in their innate resistance to decay and are most resistant when relatively dry and firm. Mature green tomatoes are more resistant to most decay pathogens than are ripe fruit. Over-ripe fruit may be attacked by organisms, such as Penicillium spp., that normally are not considered decay pathogens of tomatoes.
Certain conditions may predispose tomato fruit to decay. For example, exposure of green tomatoes to temperatures below about $55^{\circ} \mathrm{F}\left(13^{\circ} \mathrm{C}\right)$, either in field, storage, or field/ storage combined, eventually leads to chilling injury, which is often characterized by poor color development and decays caused by certain fungi (Lyons and Breidenbach 1987). Water congestion, a second predisposition that compromises a fruit's natural resistance to decay, occurs when water partially or completely fills a fruit's intercellular air spaces. The congested tissues lose their innate resistance to decay and furnish nutrition to various microbes. Green tomatoes are normally resistant to sour rot caused by Geotrichum candidum (Butler 1960). However, if green fruit have been chill injured or are congested with water, sour rot will develop and produce a watery decay.

Once harvested, fruits and vegetables have a limited postharvest life. They no longer receive water or nutrition from the plant. Naturally occurring senescence in produce leads to a softening of the tissues and often a loss of preformed antimicrobial substances. These changes in the fruit or vegetable also make it less desirable to consumers. This correlation between senescence, susceptibility to decay and loss of edible quality has a great impact on decay control methods. Handling methods that preserve the freshly harvested quality of the crop, such as cooling, are likely to minimize the development of decay.

1. This document is HS866, one of a series of the Horticultural Sciences Department, UF/IFAS Extension. Original publication date February 2002. Revised December 2004, November 2009, July 2013, January 2017, and September 2020. Visit the EDIS website at http://edis.ifas.ufl.edu.

2. Jerry A. Bartz, associate professor, Plant Pathology Department, UF/IFAS Extension, Gainesville, FL; Gary E. Vallad, associate professor, Plant Pathology Department, UF/IFAS Gulf Coast Research and Education Center, Wimauma, FL 33598; and Steven A. Sargent, professor, Horticultural Sciences Department; UF/IFAS Extension, Gainesville, FL 32611. The authors acknowledge the assistance of Corrine Hermle, former graduate in the Plant Pathology Department, for figures 2 and 14 and Steve Jordan, former postdoctoral trainee, for Figure 10. 
Pathogens are present in all production areas and are most numerous when the weather becomes warm and wet. Movement of weather fronts or tropical storms through production areas can also affect the susceptibility of tomato fruit to decay (Bartz, Sargent, and Scott 2012). Fruit decays can be minimized by the employment of strict sanitation measures along with careful handling. This bulletin is designed to supplement field scouting and identification guides by

a) describing postharvest decay pathogens important to Florida tomato packers and shippers,

b) presenting sanitation guidelines for controlling decay pathogens during harvest and handling operations,

c) offering appropriate storage temperature options.

\section{Identifying Postharvest Pathogens}

The two primary classes of microorganisms that cause decay are bacteria and fungi. Certain other types of plant pathogens, such as viruses and nematodes, may be responsible for postharvest losses, but do not cause progressive deterioration of tomatoes. For example, the symptoms of tomato spotted wilt virus (TSWV) may not be apparent on freshly harvested green fruit. However, as the infected fruit ripens, a discoloration associated with the disease clearly renders the fruit unmarketable.

\section{Bacterial Postharvest Diseases}

Bacteria are single-celled organisms that can rapidly multiply and spread, particularly in water. Even a thin coating of water, such as on a wet fruit, leaf, field bin surface, or packinghouse machinery, can support the rapid movement and growth of the organism. Bacterial growth is normally slimy and without structure, and films of bacteria may form on wet surfaces. These films become sticky with time, particularly if they begin to dry. Fresh films normally disperse readily in water, whereas sticky or even hardened films (known as biofilms) resist wash efforts (see Packinghouse Sanitation section below), but do shed bacteria.

Certain bacteria, called the soft rot bacteria, cause a common, and potentially devastating, postharvest disease called bacterial soft rot. The pathogen liquefies fruit tissue by breaking down the pectate "glue" that holds plant cells together (Figure 1). Bacterial soft rot can be caused by at least four different bacteria.

The most common and aggressive "soft rot" bacteria are strains of Pectobacterium carotovorum. These bacteria are ubiquitous and have been found in places as diverse as ocean spray off the coast of California, snow in the Rocky Mountains, well water in a few locations, and surface water nearly everywhere. These soft rot strains can grow on the surface of plants and cause a soft rot of succulent plant parts, particularly during wet weather. They can be spread by rainstorms, insects, harvest crews, picking containers, and packinghouse equipment. Fortunately, these bacteria cannot penetrate directly through the waxy skin of a tomato. However, small wounds, even the size of abrasion from sand particles or tiny cuticle cracks, enable the bacteria to infect fruit tissues. Additionally, fruit may internalize the bacteria (see discussion below on internalization). Cells inside the fruit lack a cuticle or other structures that protect the fruit surface from direct pathogen attack. Consequently, soft rot bacteria that are internalized initiate lesions that begin inside the fruit (Figure 2).

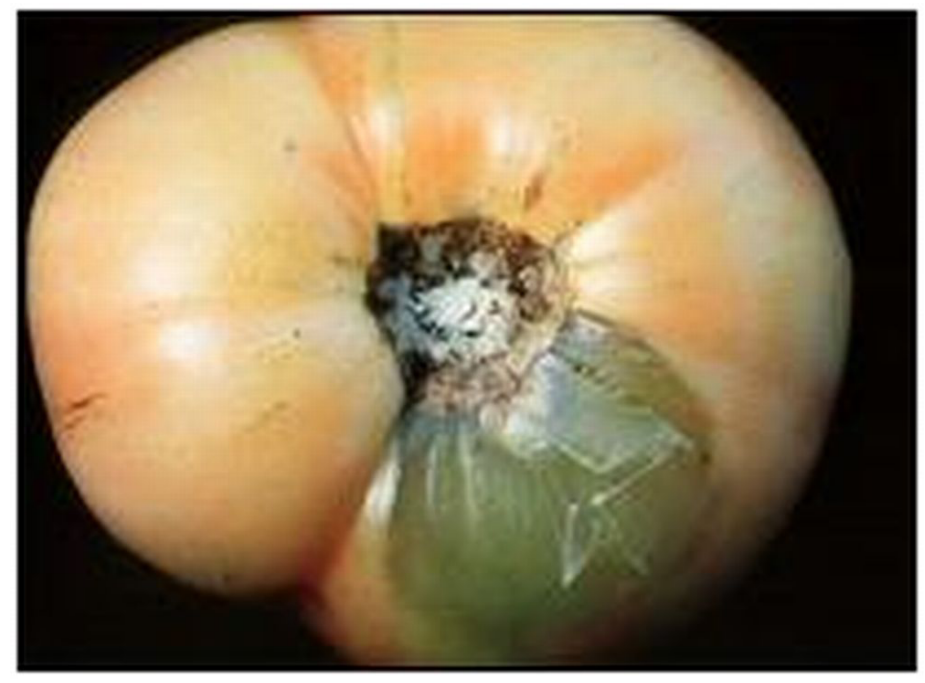

Figure 1. A typical bacteria soft rot lesion.

Credits: J. A. Bartz

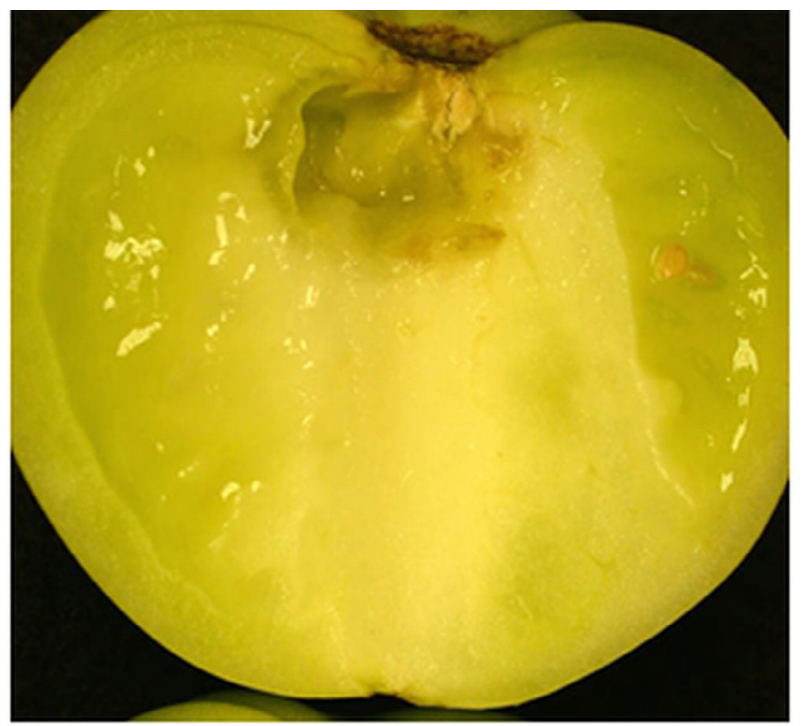

Figure 2. Sliced tomato showing a soft lesion that began under the fruit's stem scar.

Credits: C. M. Hermle 
Certain species of Pseudomonas, Xanthomonas and Bacillus can also cause a soft rot of tomatoes. The mode of action, symptoms and control for these pathogens are nearly identical to those for Pectobacterium.

Soft rot bacteria readily disperse in a water suspension (aqueous suspension) and are quickly spread by dew or raindrops on plant surfaces, water in dump-tanks, flumes, or washers, and the juice from decaying fruit. Soft rot bacteria can even pass from one fiberboard shipping carton to an adjacent carton as fluids from a wet spot on one carton seep into an adjacent carton. High relative humidity (90\%-95\%), frequently found in ripening rooms, packed cartons, or masses of harvested fruit (field bins, gondolas), promotes the survival of these bacteria as well as their ability to infect wounds. Free water on wound surfaces absolutely promotes infection. Fruit temperatures above $86^{\circ} \mathrm{F}-95^{\circ} \mathrm{F}\left(30^{\circ} \mathrm{C}-35^{\circ} \mathrm{C}\right)$ are associated with a rapid development of bacterial soft rot, such that the period between inoculation and visible soft rot may be less than 18 hours.

A second type of bacterial decay is a sour-rot type disease caused by bacteria that produce lactic acid (Lactobacillus spp. or Leuconostoc spp.). These organisms are also ubiquitous in nature and are similar to those responsible for the pickling process in brined cucumbers. Several environmental and fruit samples collected by the author from different packinghouses contained these lactic acid bacteria. They are potentially present on equipment, on fruit coming in from the field and in the liquid from rotting fruit. In laboratory tests with tomatoes, these bacteria produced a slightly softened lesion like the other soft-rot bacteria, but the wound liquid was quite acidic and smelled as if the tissues had been pickled. Unlike the sour-rot disease caused by fungi, there was no evidence of fungal structures. These lactic acid bacteria are gram-positive.

\section{Fungal Postharvest Diseases}

Fungi are filamentous microorganisms commonly known as molds or yeasts. In nature, they often appear thread-like, cottony, or as yeast-like scum. Many fungal species can cause fruit decay in tomatoes and, like bacteria, usually flourish under warm moist conditions. Fungi are generally more difficult to eradicate than bacteria, in part because fungal cells are much larger, more resilient to sanitizing agents and produce spores that are relatively resistant to drying and other environmental stresses. Spores are singleto few-celled reproductive structures that may be dispersed by water or wind as well as animals and equipment.
The sour-rot pathogen, Geotrichum candidum, is a type of yeast. Its growth on lesions on fruit resembles a thick, gelatinous mass similar in appearance to cottage cheese. The lesions themselves may initially be watery (Figure 3) but later become coated with pathogen growth (Figure 4) and remain relatively firm unless a secondary infection by a soft rot bacterium occurs. However, the odor of these lesions is similar to that produced by lactic acid bacteria, hence the disease name, sour rot.

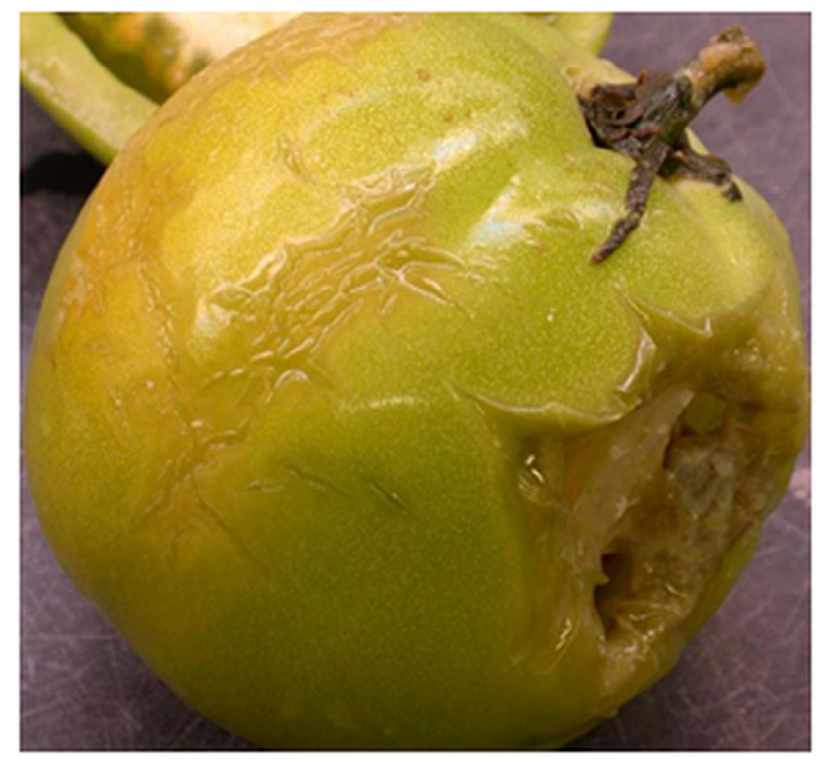

Figure 3. Watery-rot phase of sour rot on water-congested green fruit. Credits: M. J. Mahovic

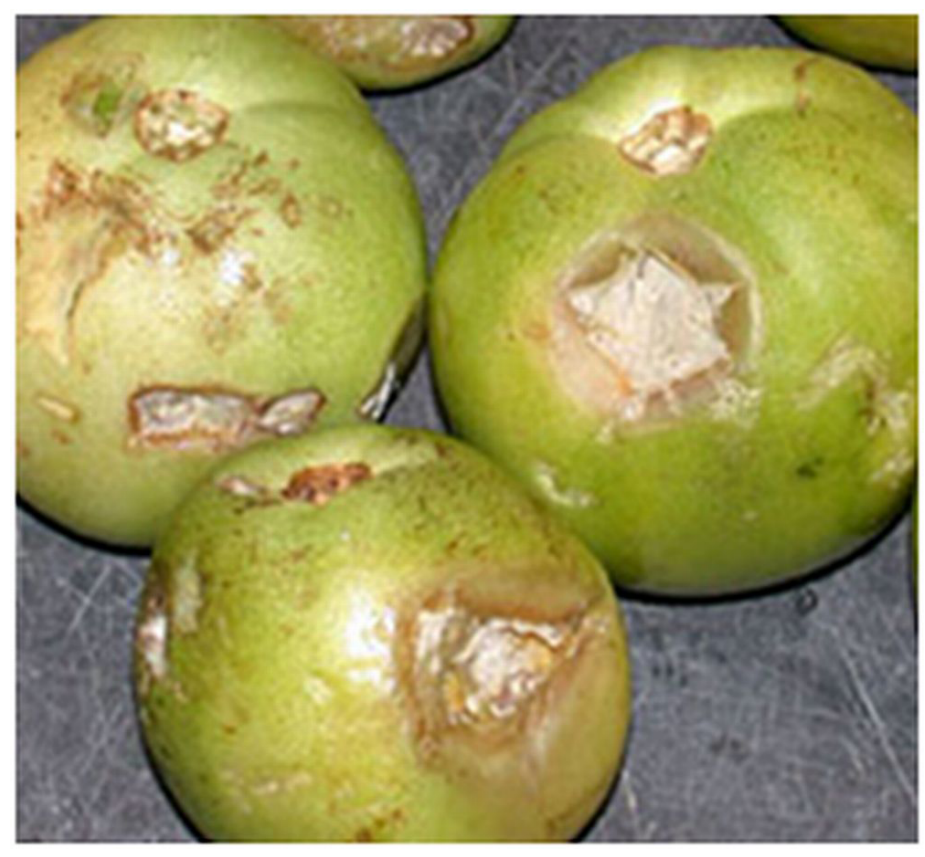

Figure 4. Sour rot lesions covered with pathogen growth. Credits: M. J. Mahovic

A second common fungal pathogen is Rhizopus stolonifer, which is in the bread mold group of fungi. This pathogen grows very aggressively. On tomatoes, Rhizopus rot appears 
water-soaked and may exude a clear liquid (Figure 5). The lesion surface may be covered with thin, cotton-like fungal structures (especially under humid conditions). Tissues within the lesion are usually held together by relatively coarse strands of fungal hyphae. Dark sporulation may crown the white tuft of Rhizopus. The mycelium can infect adjacent fruit through natural openings or mechanical wounds, creating nests of mold and diseased fruit (Figure 6). The spores are extremely small and lightweight, and can be carried by air currents to infest new fruit, potentially far from the source. Under favorable conditions, Rhizopus has been observed to grow short distances on dry surfaces, such as pallets and cartons, and it may survive for months in fruit residues left in picking containers and field bins.

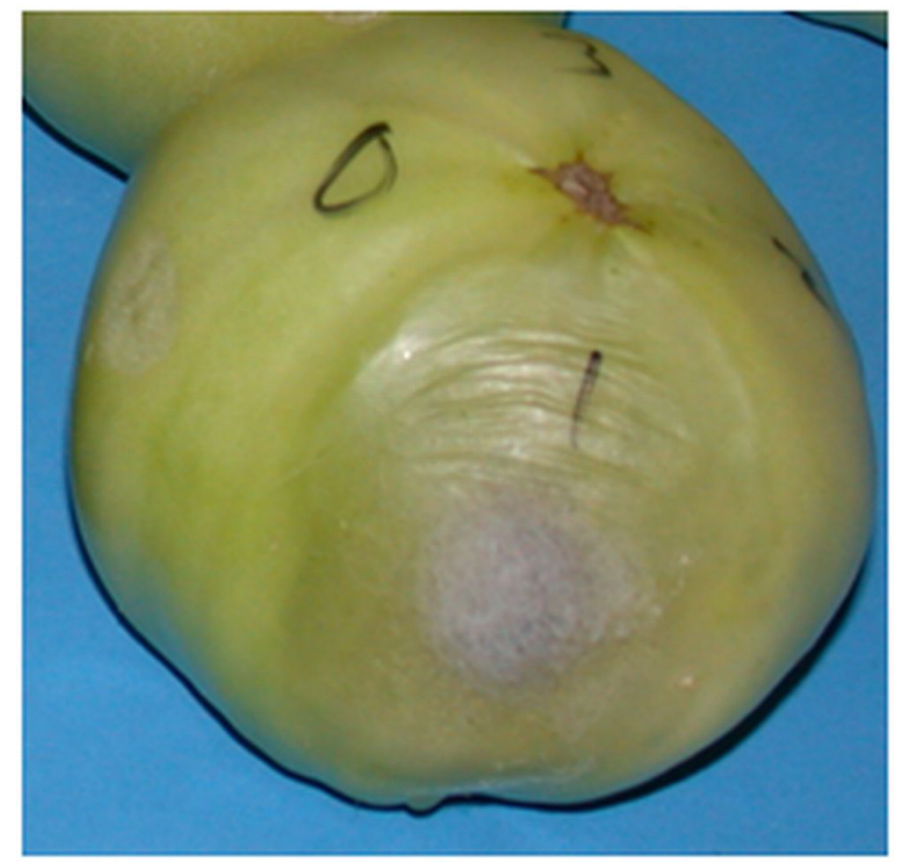

Figure 5. Rhizopus rot on green fruit.

Credits: M. J. Mahovic

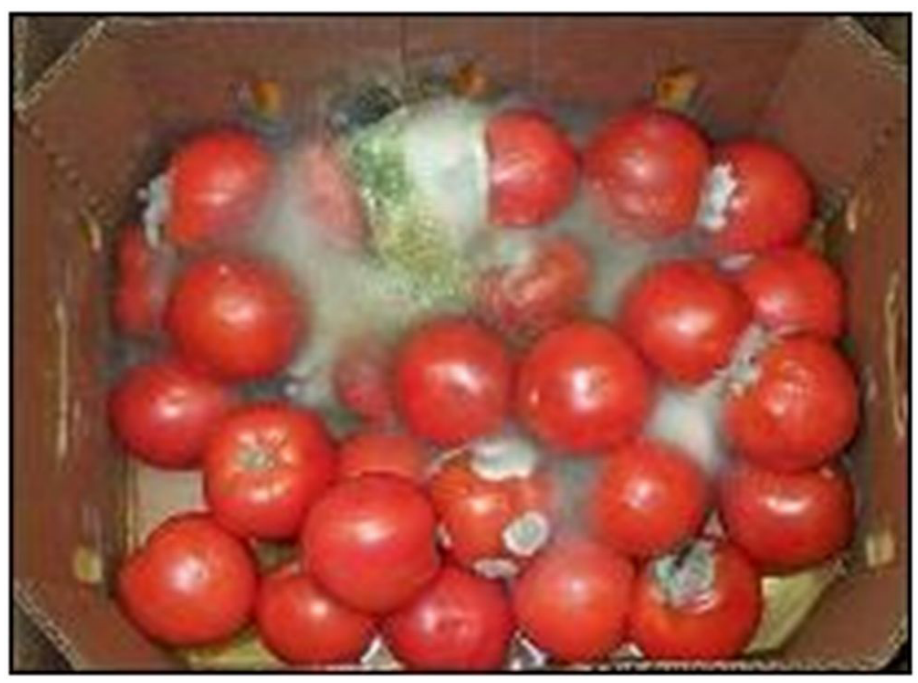

Figure 6. A carton of tomatoes with "nested" Rhizopus rot (and secondary fungi).

Credits: M. J. Mahovic
Phytophthora, or buckeye rot, usually causes a circular rot that looks water-soaked, later darkening in the center and/ or becoming overgrown with sparse, white mycelia (Figure 7). The pathogen belongs to a group of microorganisms often referred to as "water molds," because their infectious propagules are dispersed by water. Therefore, buckeye rot often develops on fruit growing near wet spots in a field. Initial symptoms appear as small stains in the fruit surface. On harvested fruit these stains may be overlooked by sorters. However, in storage the small stains enlarge, and the pathogen can move from diseased to adjacent healthy fruit, leading to the term "buckeye nesting" or "snowballs" (Figure 8). Buckeye rot is rare during normal production seasons but is not uncommon during wet periods, particularly if standing water exists in fields.

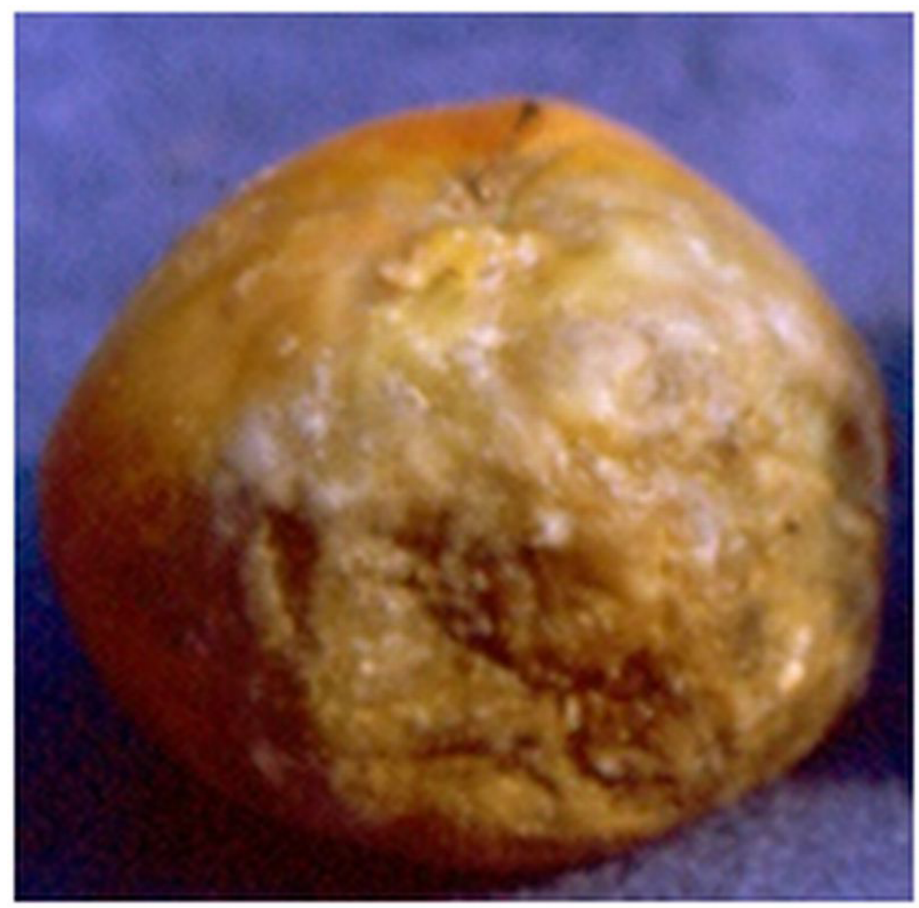

Figure 7. Advanced buckeye rot.

Credits: J. A. Bartz

Black mold rot often appears on the shoulders, by the stem scar, or on the blossom end of fruit that has been injured by chilling, calcium deficiency, sun exposure, climatic factors that cause fruit cracking (e.g., high temperatures and high rainfall), pesticide phytotoxicity, imperfectly closed blossom-end pores (catfacing), and, perhaps, harvests during cold weather. Several different pathogens may cause black mold rots including Alternaria arborescens, Stemphyllium botryosum, or S. consortiale. Lesions are initially sunken or flattened areas associated with a crack or other injury that quickly become covered with a dark brown to black mold (Figure 9). Internal lesions may develop from an infected stylar pore or vascular strand connected to the stem scar (Figure 10). In particular, dry locular cavities that 
have lost their gel due to a severe internal bruise (Figure 11) are likely to develop internal blackspot. This disease usually does not spread from fruit to fruit in boxes. Green fruit are quite resistant unless exposed to chilling temperatures, blossom-end rot, or damage by certain spray mixtures.

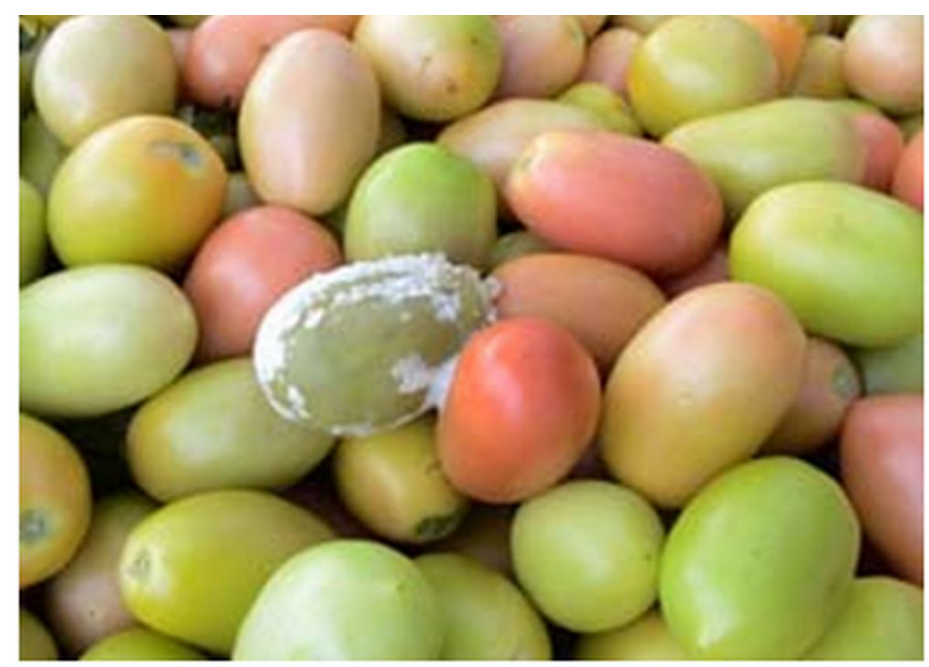

Figure 8. Water mold covering infected fruit (snowball) and spreading to adjacent fruit.

Credits: S. A. Sargent

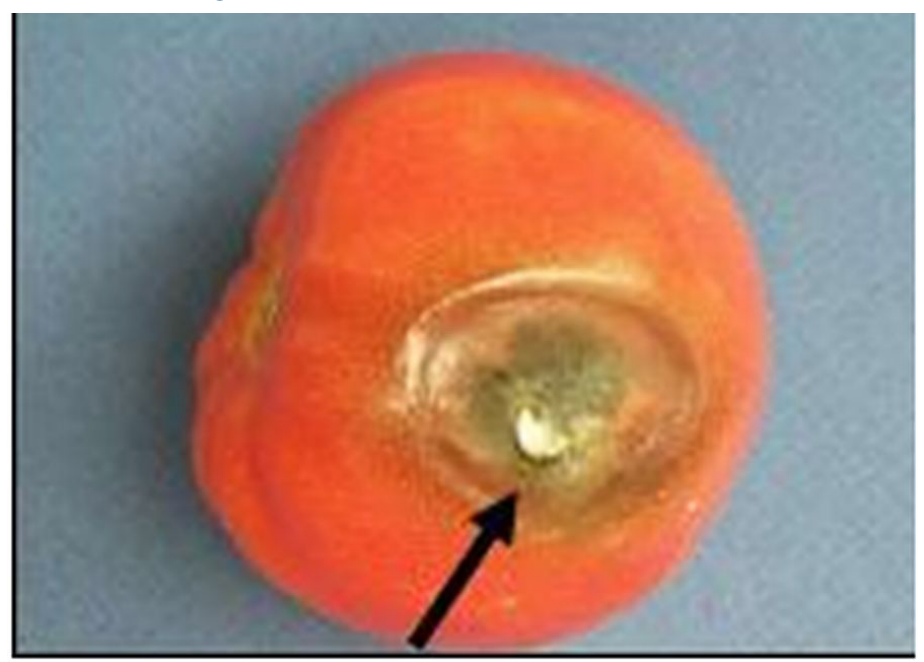

Figure 9. A fruit with a fingernail wound (arrow) that later developed into black mold rot.

Credits: M. J. Mahovic

Several other fungi can infect tomato fruit in the field and later lead to postharvest decays. However, these, like black mold rot, rarely spread among fruit within a box and can be considered minor decay problems for Florida tomatoes. However, each of these diseases can provide entry points for more aggressive decays such as bacterial soft rot, Rhizopus rot, or sour rot. Fusarium rots can develop on tomatoes that are in contact with the soil and/or have been chilled in the field. The surface of the lesions is covered with fluffy white mycelium with undertones ranging from shades of pink of orange to purple. Target spot (Corynespora cassiicola) develops on tomatoes (plants and fruit) during long periods of high moisture and warm ambient temperatures. Fruit lesions are small, dark brown spots that enlarge and split open as the fruit ripens. If the disease becomes severe in the field, the plants will defoliate, thereby exposing the fruit to sunlight, which increases surface cracking and sun damage. Phoma rot (Phoma destructiva) begins at the blossom end of fruit as sunken black spots with water-soaked edges and dark-centered rings, similar in appearance to buckeye rot. Anthracnose, caused by Colletotricum spp. develops on primarily ripe to overripe fruit, usually during wet, warm conditions. Cladosporium rot, caused by Fulvia fulva, develops under highly humid conditions, usually in greenhouses or under high-tunnel production systems.

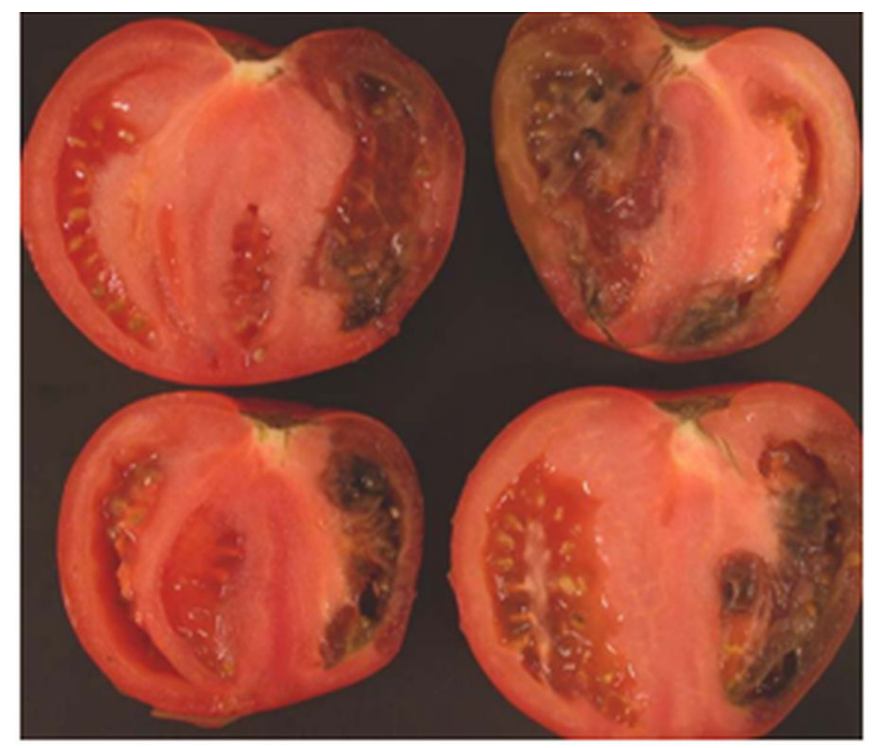

Figure 10. Internal black mold rot lesions developing in fruit harvested (as pinks) during a cold morning.

Credits: S. Jordan

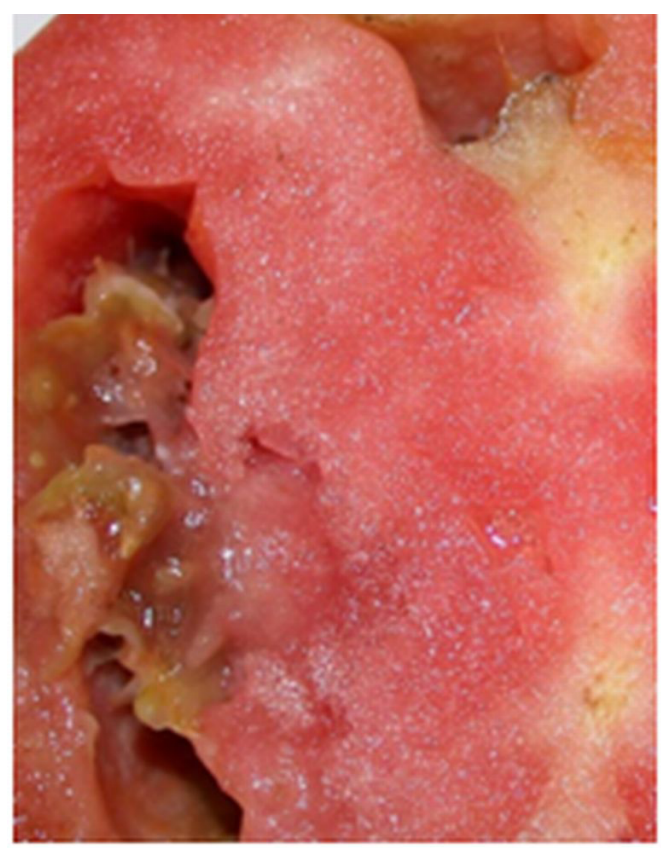

Figure 11. Dry locular cavity due to severe internal bruise. Credits: S. Jordan 
Gray mold (Botrytis fruit rot) is rarely observed among field-grown tomatoes in Florida, although it is the major decay of fresh-market tomatoes produced in cool, humid Mediterranean climates, such as during certain seasons in California. It can appear in Florida during cool, wet weather, particularly if the soils are low in calcium and the plants have started to senesce. The pathogen, Botrytis cinerea, has a wide host range and is an excellent saprophyte. Fuzzy gray-colored mold on the lesion surface is typically diagnostic. At harvest, some of the fruit infections can be latent or appear as tiny lesions that escape detection on the packing line. However, the infections continue to develop during shipping and marketing, causing the affected fruit to become unmarketable. Botrytis fruit rot can spread within a box, leading to the production of nests. Certain infections by $B$. cinerea fail to resume development as the fruit ripens. These lesions may appear as light, often circular areas called ghost spots.

Storage molds can develop on fruit that have been gassed or stored for prolonged periods of time in humidified rooms. These molds grow over the stem scar, attached stem, blossom scar or other corky areas (Figure 12). They are generally nonpathogenic and do not penetrate into the flesh of the fruit. However, the mold detracts from the appearance of the fruit and may lead to shipment rejection.

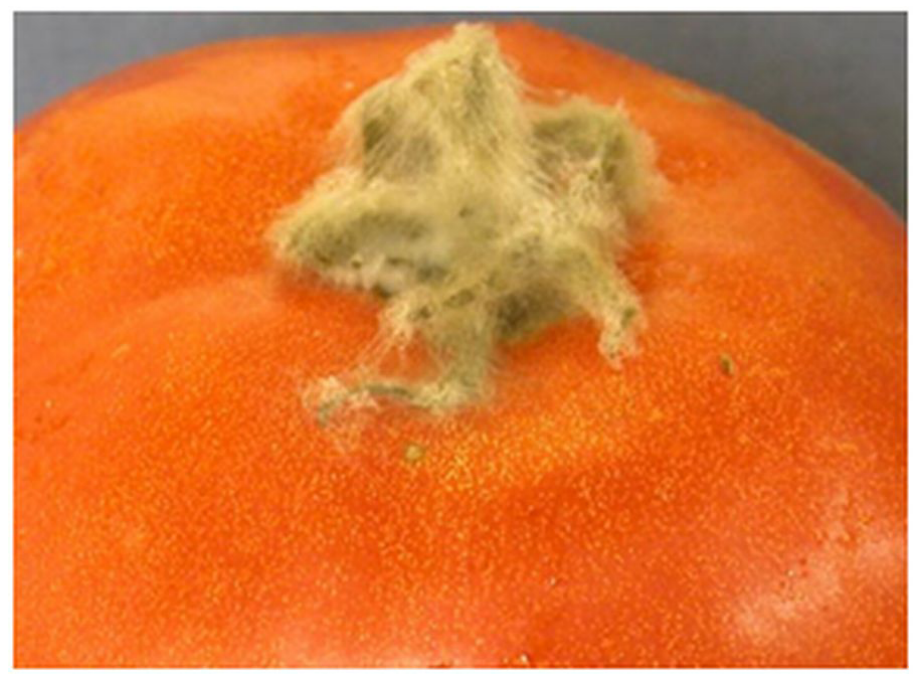

Figure 12. Storage mold covering an attached stem but without evidence of penetration into the fruit.

Credits: M. J. Mahovic

\section{Controlling Pathogens}

\section{Field Sanitation}

The implementation of good agricultural practices (GAPs) in the field and at harvest greatly aids in the prevention of most postharvest fruit rots. However, periods of persistent rainfall, persistent fogs following rainfall, cool mornings, or exposure to chilling temperatures in the field can increase decay losses despite the GAPs. In addition to disease control strategies, the GAPs should include control of chewing insects that create wounds in fruits. Plant management should promote air movement over plant surfaces, particularly those hidden within the canopy of the plant. This air movement is necessary to dry guttation, dew or rainfall from plant surfaces. Tying and harvest operations should be postponed until free moisture has dried from the plant canopies. Because wet plants are more prone to mechanical injury (creating wounds), the fruit may be congested by water, which promotes the spread, survival, and growth of decay pathogens. Drip, furrow, or seep irrigation is preferred to overhead irrigation because overhead irrigation moistens plant surfaces.

\section{Food Safety Considerations}

Certain human pathogens, including bacteria belonging to species of Salmonella, Shigella, Escherichia, or Listeria and certain viruses, may survive on or in fresh tomato fruit. Under certain conditions bacteria may actually multiply. Sources of the human pathogens include infected workers, domestic and wild animals, raw manure, contaminated equipment/containers/trucks, nearby pastures or animal confinements as well as open surface water such as swamps or lakes. Dispersal to developing or harvested fruit can occur by rain splash, aerosol drift, run-off water, overhead irrigation with surface water, and spray applications involving use of surface water.

Because human pathogens do not visibly affect the fruit, their presence may be unknown at the time of packing and marketing. However, consumers can be infected, and an outbreak can have a devastating effect on not only the implicated packinghouse, but also the entire industry. Fortunately, the same sanitation steps that control fruitrotting pathogens normally control human pathogens.

All growers, packers, and shippers of Florida tomatoes are required by state law to follow regulations established by the Florida Department of Agriculture and Consumer Services (FDACS 2013). For more information regarding these regulations and other food safety issues in fresh produce handling, see the references at the end of this publication.

\section{Packinghouse Sanitation}

The potential for development of fruit decay after harvest is lowest if the plants are dry and free of decay at the time of harvest. However, because harvested fruit will virtually always have some level of contamination by microorganisms that can cause decay, steps must be taken to prevent spread of these potential pathogens to wounds and internal 
sites when the tomatoes are transferred from the picking container (field bin, gondola) to the packing line and into cartons (Figure 13). Sufficient sanitation requires the inactivation of freshly introduced microbes within about 10 seconds of initial contact in the dump tank water.

Suspended microbes that are not killed within 10 seconds may internalize in wounds or stem scars on tomatoes where they are protected from antimicrobial treatments. "Vigilance" is the key word in preventing decay. In the following section, key considerations are presented for establishing good management practices (GMPs) to maintain sanitary conditions during tomato packing and handling.

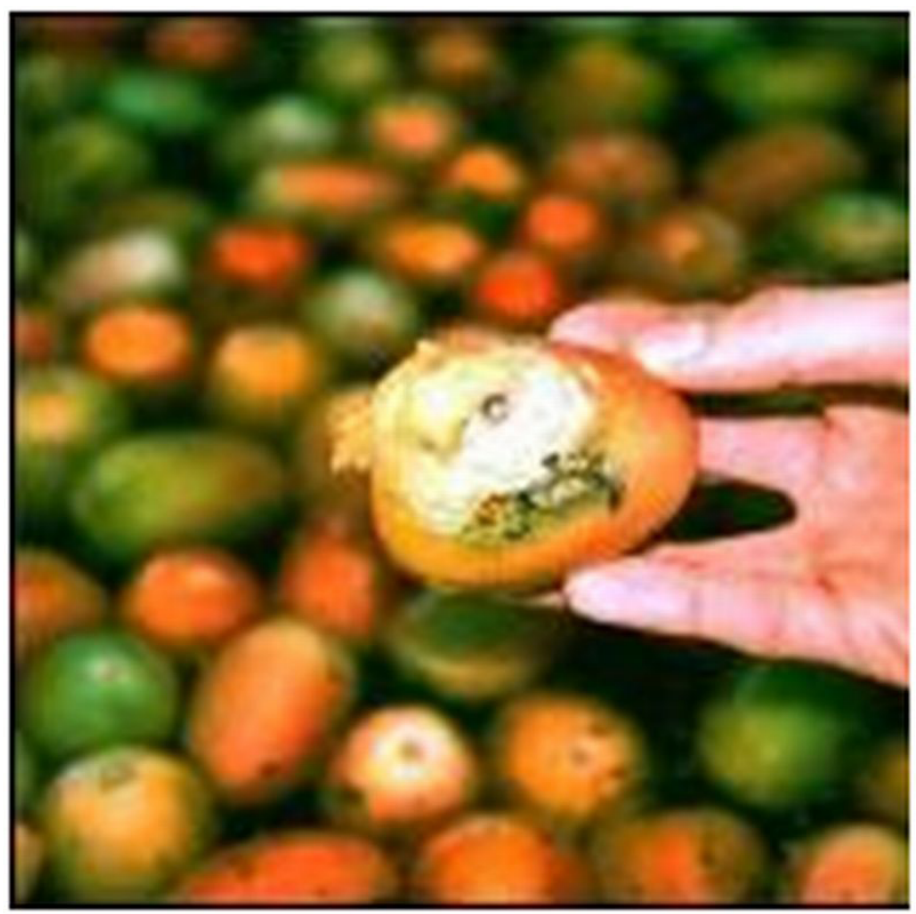

Figure 13. An infected tomato can spread inoculum to healthy tomatoes in the flume/dump tank.

Credits: S. A. Sargent

Microbe internalization: The movement of living bacteria or fungal structures into fruit tissues (the air spaces between cells) is known as internalization and leads to a situation that cannot be corrected. Frequently, the internalization pathway follows water channels, which feature a continuous water connection between the fruit's surfaces and its interior cells. Such channels are present when the fruit surface is water congested, as when tomatoes are harvested from wet plants. Upon contacting water channels, water containing suspended particulates (such as microbe structures) is rapidly drawn into the fruit by internal capillary forces in less than 60 seconds. The most frequent sites for water channels are fresh wounds and water-congested stem scars. By contrast, dry surfaces, whether old wounds or stem scars, are protected against water internalization by an air layer and by fruit wax.
Microbe infiltration: In contrast to internalization, dry surfaces can be penetrated by water through a process called infiltration. Infiltration occurs when the external pressure of the liquid contacting the fruit surface overcomes the natural hydrophobic resistance of the wax and/or presence of air bubbles in openings in the tomato surface, particularly the stem scar. For example, infiltration occurs when warm tomatoes are submerged in cool water as briefly as 5-10 minutes. As the fruit cools, air inside its tissues contracts, creating a vacuum that draws the surrounding water (and suspended microbes) into openings such as the stem scar or catface at the blossom end (Figure 14). Infiltration can also occur when fruit are struck by a high-pressure stream of water such as when tomatoes are flumed from a gondola or if there is an excessive amount of fruit in a dump tank or flume that causes some fruit to be submerged several layers deep.

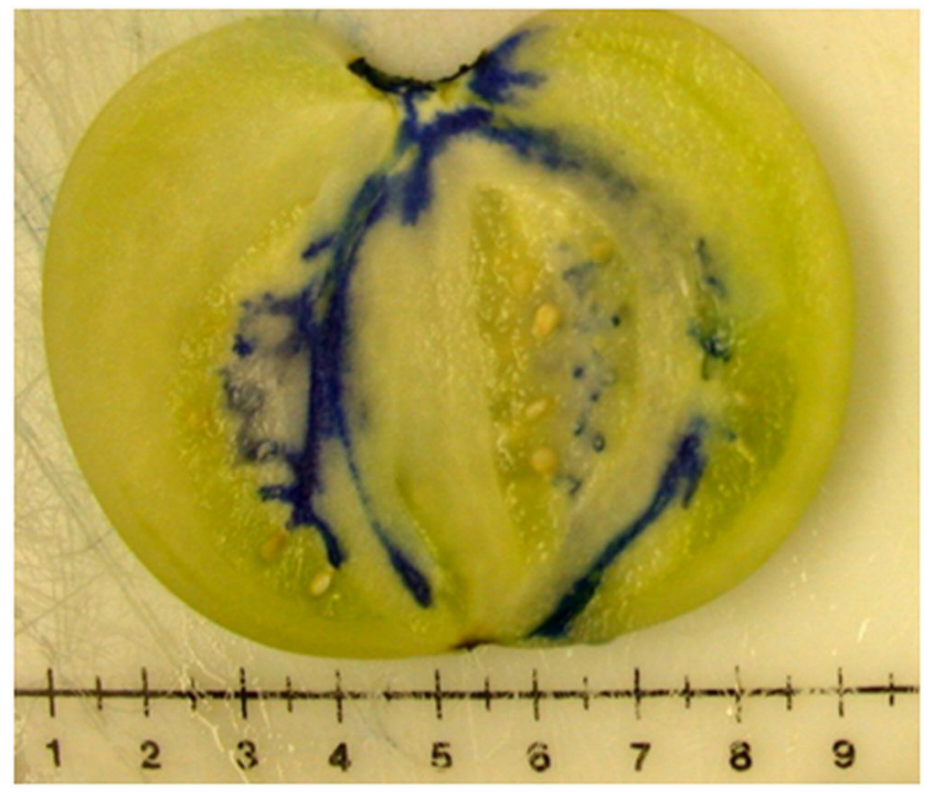

Figure 14. An extreme infiltration of the stem scar and blossom-end scar by a dye solution illustrates that microbes could be internalized under certain conditions.

Credits: C. M. Hermle

Several procedures can minimize water infiltration into tomatoes:

- Heat dump-tank water $10^{\circ} \mathrm{F}$ (about $5^{\circ} \mathrm{C}$ ) above the incoming tomato pulp temperature to eliminate fruit cooling. Although this has been recommended, limiting fruit dwell time in the water to less than 60 seconds reduces the chances for major fruit cooling in all but situations where the water is very cold and the fruit very warm. Florida well water comes out at about $77^{\circ} \mathrm{F}\left(25^{\circ} \mathrm{C}\right)$ for the main production areas of the state. 
- Prevent fruit from accumulating in more than a single layer in the dump tank during unloading by making sure the capacity of the packing line is not exceeded.

- Minimize fruit contact with large streams of water such as during the transfer of bulk loads from a gondola to the dump tank.

- Limit tomato residence time in dump tanks and flumes to less than 2 minutes, but note exception above if the water is not warmed.

Recirculated water sanitation: Chlorine has been widely used in water sanitation for many years. Alternatives to water chlorination for tomato dump tanks have been proposed and several have been tested; however, none of the alternatives appear to be as efficient, inexpensive, easy to apply, and effective as chlorine. A major factor in the effectiveness of chlorine is how rapidly it kills microbes. In laboratory tests designed to simulate packinghouse conditions, soft rot bacteria were mixed in water, and tomatoes were wounded, then immersed in the contaminated water before being rinsed with clean water. Decay later developed on tomatoes that were immersed for only 5-10 seconds. Hence, soft rot bacteria required only 5-10 seconds of contact before becoming internalized where they could not be washed off fruit. If $10 \mathrm{ppm}$ free chlorine at, $\mathrm{pH} 6.5$ was in the water, the fruit were protected from inoculation and were not infected.

Basic chlorine chemistry: Water chlorination requires a few simple management steps if it is to be effective. These steps ensure that the most active forms of chlorine are present at sufficient concentrations to prevent crosscontamination of fruit in recirculated water systems. The steps are entirely based on how chlorine acts as a sanitizing agent. Three factors have a profound influence on chlorine concentration and activity, namely (i) chlorine demand, (ii) water $\mathrm{pH}$, and (iii) water temperature.

Chlorine demand: Most bactericides and fungicides inactivate microorganisms by inhibiting an essential process or by interrupting vital functions of the cellular membrane of the pathogen. In contrast, chlorine reacts with and destroys various essential chemicals on and within the microorganism. As these compounds are chemically changed, the microbe is first stopped from growing and then is completely inactivated. Active chlorine is destroyed during this process. Moreover, active chlorine reacts with structures on the fruit as well as with chemicals and materials that accompany the fruit. Thus, the active chlorine concentration decreases as loads of fruit are dumped into the system. The sum of all reactions that destroy active chlorine is called chlorine demand. If the recirculated water is to remain sanitary, chlorine additions must exceed chlorine demand. Moreover, a certain level of the most active forms of reactive chlorine must be maintained. Free-chlorine is the sum of the three most active forms of chlorine in chlorinated water (see next section).

Water $\mathbf{p H}$ : Water $\mathrm{pH}$ affects the efficacy of free chlorine by regulating the ratio of the three active forms: elemental chlorine, hypochlorous acid, and hypochlorite ion.

Together, these three forms compose the free chlorine concentration of a solution. At $\mathrm{pH}=6.0,97 \%$ of the free chlorine is in the form of hypochlorous acid, whereas the remainder is hypochlorite ion; at $\mathrm{pH} 9.0$ these ratios reverse. At $\mathrm{pH} 7.5$, the ratio of acid to ion is approximately 50:50. Unless the $\mathrm{pH}$ drops below about 5.0, chlorine gas concentrations in these solutions are not high enough to be a factor in water sanitation or worker hazards. Thus, the most antimicrobial form of free chlorine in packinghouse dump tanks and flumes that are properly managed is hypochlorous acid, which is from 20 to 300 times more toxic to microbes than the hypochlorite ion. However, it is not practical to maintain the solution $\mathrm{pH}$ at 6.0 so that most of the free chlorine is hypochlorous acid because this increases equipment corrosion. Therefore, maintaining the water $\mathrm{pH}$ near $\mathrm{pH} 7.0$, or neutral, is a good compromise. At this $\mathrm{pH}$, hypochlorite ion rapidly converts to hypochlorous acid as the latter is lost to demand reactions. Water in Florida is generally alkaline, and food-grade acids or carbon dioxide gas are effective acidifiers.

Water temperature: Chemical reactions such as the oxidation of microbes by chlorine occur more rapidly as the temperature of the reactants increases. Therefore, heating dump tank water, while helping to reduce microbial infiltration, as explained above, enhances free chlorine's antimicrobial activity, but at a cost of destabilizing the solution (more rapid loss of free chlorine) and more equipment corrosion.

\section{Chlorine monitoring in recirculated water systems:} Incoming loads of fruit are likely to vary considerably in how much chlorine demand they have when dumped into the water. Chlorine demand factors such as spray residues, leaf debris, damaged fruit and soil films (particularly if accompanied by free moisture) vary from field to field and even from hour to hour. Maintenance of effective levels of free chlorine along with an appropriate $\mathrm{pH}$ and water temperature is necessary for effective sanitation and methods for monitoring these conditions are described in the following section. 
Manual measurement and control of recirculated water conditions was the standard method used prior to the development of automated systems. Historically, packinghouse managers developed schedules for water sanitation based on frequent manual measurements of chlorine concentration and solution taken during packing. The resulting schedules relied on the timely addition of chlorine and $\mathrm{pH}$-adjusting products that were added either continuously or periodically during the packing day. The reliability of manual measurement and control is unclear. A high degree of manager diligence is required. Discussions with packinghouse managers have indicated that time constraints encountered during a typical workday often interfere with the manager's ability to pay attention to detail. The free chlorine concentration recommended for such a system (100-150 ppm) was higher than that required to kill pathogens within 1 minute (about $40 \mathrm{ppm}$ ), but it provided a buffer when measurements or product additions were missed or in the case when chlorine demand was not uniformly distributed in the flume water (Hicks and Segall 1974).

The rate and number of fruit unloads were other factors in the effectiveness of chlorine product additions. However, basing chlorine additions only on fruit unloads is risky because the cleanliness of the incoming tomatoes affects chlorine demand in ways that are not entirely clear.

Generally, water clarity decreases as bins are unloaded and the water washes waxes, soil, dust, pesticide residues, etc., from fruit surfaces. A portion of the suspended particulate matter as well as dissolved chemicals reacts quickly with chlorine while other portions react more slowly. Chlorination of murky or sediment-laden water is more difficult to manage as compared to clean water systems. For example, it is nearly impossible to maintain a free-chlorine residual in flumes receiving soil-laden root crops such as potatoes. With tomatoes, maintaining free chlorine residuals becomes more difficult as the workday progresses and the water becomes more turbid. Measurement of free chlorine/ $\mathrm{pH}$ is the only reliable way to assess the sanitation potential in the recirculated water surrounding the floating fruit. Therefore past records of chlorine use and unloads are useful to develop a treatment schedule, but if there is any doubt, managers are advised to make more frequent freechlorine/pH tests and to keep a record of those results in order to ensure that the system is always properly sanitized.

Automated measurement and control systems continuously measure and control chlorine concentration and $\mathrm{pH}$ using ORP probes, $\mathrm{pH}$ probes, a programmable controller and solution pumps. However, since probes can foul without warning, giving inaccurate control, we recommend that manual readings be made and recorded every 30 to 60 minutes to confirm proper equipment operation. Handheld electronic ORP and $\mathrm{pH}$ meters, free chlorine test kits and test strips are very reliable for manual readings along with a measurement log. Recordkeeping is critical for traceback and evaluation/resolution should a decay outbreak occur during later handling, shipping or marketing. Many automated systems print or electronically store these data for recordkeeping purposes.

Based on the above discussion on postharvest pathology and chlorine chemistry, dump tank water can be kept sanitary by constantly maintaining 150 to $200 \mathrm{ppm}$ free chlorine at a $\mathrm{pH}$ of 6.5 to 7.5. Under these conditions the water will not disperse or accumulate decay pathogens or human pathogens. Moreover, there would be sufficient free chlorine excess in the dump tank water to cover sudden surges in chlorine demand, such as during bin dumping.

A more thorough explanation of chlorine chemistry, $\mathrm{pH}$ effects, chlorine sources, measurement and mixing guidelines is available (Ritenour, Sargent, and Bartz 2008).

\section{Other Sources of Inoculation}

Pathogens can be transferred to fruit through contaminated equipment or workers. Therefore, field bins, gondolas, harvest aides, and harvest containers should be regularly cleaned and disinfected. All workers should be instructed on the importance of sanitation and on proper personal habits, including handwashing. Restrooms should be regularly cleaned and sanitized. Handwashing stations should be conveniently located outside of restrooms as well as near the sorting belts on packing lines. Workers should be encouraged to wash their hands frequently throughout the day. Workers who are or have been recently ill should not be allowed to work directly with fruit. See De et al. (2019) for more information on setting up food safety programs,

Mechanical injuries, such as cuts, punctures, abrasion, and bruises, provide likely sites for infection to occur. Gentle handling procedures during harvest operations should be enforced to minimize fruit injuries. Thorough sorting of injured fruit is essential to minimizing later development of postharvest decays. The sorting area of the packing line should have good lighting so that damaged fruit are readily detected and culled. Tomatoes can be cross-contaminated by certain types of decay pathogens and other undesirable microorganisms via air movement, insects, and animals. Therefore, the packing area, ripening rooms, and storage 
areas must be kept free of rodents, birds, and insects, which can disperse various undesirable microorganisms or even be the source of such organisms. Culled fruit can harbor pathogens, enable pathogens to multiply, and attract insects and other pests. Consequently, cull fruit should be continuously and promptly removed from the area. Trucks and trailers used to transport tomatoes should be inspected for cleanliness and cleaned and sanitized prior to being loaded. If the truck has previously hauled animal products, it should be steam cleaned before it is allowed to haul tomatoes.

Prompt cooling has been shown to reduce decay. Tomatoes are often harvested at temperatures that are ideal for decay development (e.g., above $86^{\circ} \mathrm{F}\left[30^{\circ} \mathrm{C}\right]$ ). In our tests, tomatoes that were inoculated with soft rot bacteria developed decay after 18 hours at $86^{\circ} \mathrm{F}$. By contrast, when inoculated tomatoes were held at $68^{\circ} \mathrm{F}\left(20^{\circ} \mathrm{C}\right)$, the recommended ripening room temperature, soft rot lesions did not appear until 3 days or longer. In fact, inoculated tomatoes often do not develop any soft rot decay when stored at $68^{\circ} \mathrm{F}$. Consequently, efforts should be made to remove field heat from freshly harvested tomatoes as soon as possible to reduce postharvest decays. Overnight storage of harvested fruit in gondolas or field bins prior to packing carries risks because the tomatoes will retain field heat and free moisture. However, in the event that such overnight storage cannot be avoided, packinghouse managers are advised to watch the cull belt carefully during packing. Any increase in the usual amount of early decay (weeping wounds or water-soaked spots) among the cull fruits is evidence that decay has started. If decaying fruit are observed in the gas or storage room, repacking may be necessary.

Extended gassing time favors mold growth during gassing and storage. Lots of tomatoes that require more than 5 days to change from green to breaker stage indicate that an unusually high proportion of tomatoes were harvested at an immature-green stage. Tomatoes that reach breaker stage within three days of gassing will have the highest quality.

\section{Summary of Recommendations}

The following recommendations are given for effective sanitation of recycled water systems and packing facilities:

a. Maintain free chlorine concentration at $150-200 \mathrm{ppm}$
and $\mathrm{pH}$ of 6.5-7.5.

b. To minimize water infiltration into the tomato, heat dump tank water and flumes to at least $10^{\circ} \mathrm{F}$ (about $6^{\circ} \mathrm{C}$ ) above tomato pulp temperature; keep immersion time less than 2 minutes and immersion depth to one layer. If dump tank water is not heated, minimize fruit immersion time to 60 seconds or less.

c. Clear tomatoes from the dump tank prior to crew breaks. Eliminate "dead spots" in the dump tank or flume where tomatoes can remain trapped for excessive periods of time.

d. Do not allow tomatoes to accumulate to more than a single layer in the dump tank, to minimize water pressure on the fruit.

e. Use an automated system for continuous chlorine and $\mathrm{pH}$ control, with manual measurements recorded hourly. If using an automated ORP system, chlorinate system to desired free concentration based on chemical analysis, measure ORP, and set ORP system to maintain that ORP. If manual measurements suggest the automated system is unreliable, the readings should be made more frequently.

f. Drain dump tank daily, remove sediments, sanitize, rinse and refill with potable water.

g. Follow local regulations on disposal of treated water, and comply with all chemical labels (for chlorine, acidifier, etc.); the container label is the law!

h. Hold tomatoes in the gassing room for as short of a time as necessary to induce ripening.

i. Plastic bins are more easily cleaned and sanitized than unpainted wooden bins. All surfaces that directly or indirectly contact tomatoes should be regularly cleaned and sanitized (picking buckets, bins, gondolas, packing line components, pallets); gassing and holding rooms walls, floors, refrigeration coils should also be regularly cleaned.

j. Quaternary ammonia compounds are effective sanitizers on equipment but are not approved for direct contact with foods; also direct contact of tomatoes on surfaces treated with these compounds can cause chemical injury. Prior to starting the packing line, all treated surfaces should be thoroughly rinsed with potable water. In particular, dump tanks cleaned with ammonia compounds should be thoroughly rinsed with water prior to refilling with chlorinated water. This rinse must be removed from the tank before it is filled with chlorinated water. If not removed from the dump tank, the ammonia compounds will react quickly with chlorine to form noxious gases. 
k. Handwashing facilities must be available at all handling points, beginning in the field. All employees must be trained to wash their hands thoroughly with soap after each restroom use. "Waterless" hand sanitizers are good supplements to proper handwashing, but are not effective sanitizers when used alone.

Sanitation must be effective at each step from harvest through handling. An effective GAP/GMP strategy for sanitation incorporates the above recommendations for adequate control of decay pathogens.

\section{For Further Information}

Bartz, J. A., S. A. Sargent, and J. W. Scott. 2012. Postharvest Quality and Decay Incidence among Tomato Fruit as Affected by Weather and Cultural Practices. PP294. Gainesville: University of Florida Institute of Food and Agricultural Sciences. https://journals.flvc.org/edis/article/view/119990.

Florida Department of Agriculture and Consumer Services (FDACS). 2013. "Tomato Good Agricultural Practices.” https://www. fdacs.gov/Agriculture-Industry/Fruit-and-Vegetables/ Tomato-Good-Agricultural-Practices-T-GAP.

De, J., C. R. Pabst, J. Lepper, R. Goodrich Schneider, and K. R. Schneider. 2019. Food Safety on the Farm: Good Agricultural Practices and Good Handling Practices-an Overview. FSHN06-01. Gainesville: University of Florida Institute of Food and Agricultural Sciences. https://edis.ifas. ufl.edu/fs135.

Hicks, J. R., and R. H. Segall. 1974. Water Chlorination for Vegetable Packing Houses. Veg. Crops Fact Sheet VC-1. Gainesville: University of Florida Institute of Food and Agricultural Sciences.

Jones, J. B., J. P. Jones, R. E. Stall, and T. A. Zitter, eds. 1991. Compendium of Tomato Diseases. St. Paul, MN: The American Phytopathological Society.

Ritenour, M. A, S. A. Sargent, and J. A. Bartz. 2008. Chlorine Use in Produce Packing Lines. HS761. Gainesville: University of Florida Institute of Food and Agricultural Sciences. https://edis.ifas.ufl.edu/ch160.

Sargent, S. A., F. Maul, and C. A. Sims. 1998. Implementing the Florida Premium-Quality Tomato Program. Proc.1998 Florida Tomato Institute. PRO 111. University of Florida/ Citrus \& Vegetable Magazine. pp. 49-54.
Schmidt, R. H., R. M. Goodrich, D. L. Archer, and K. R. Schneider. 2003. General Overview of the Causative Agents of Foodborne Illness. FSHN033. Gainesville: University of Florida Institute of Food and Agricultural Sciences. https:// edis.ifas.ufl.edu/fs099.

Simonne, A., M. A. Ritenour, J. K. Brecht, S. A. Sargent, and K. R. Schneider. 2004. Proper Handwashing for Produce Handlers. Pub. FCS8762-Eng. Gainesville: University of Florida Institute of Food and Agricultural Sciences. https:// journals.flvc.org/edis/article/view/111977.

U.S. Dept. of Health and Human Services. Center for Food Safety and Applied Nutrition. 1998. Guide to Minimize Microbial Food Safety Hazards for Fresh Fruits and Vegetables. Washington, D.C.: Author. http://www.in.gov/isdh/ files/GuideToMinimize.pdf.

White, C. 1999. Handbook of Chlorination and Alternative Disinfectants ( $4^{\text {th }}$ ed.). New York, NY: John Wiley \& Sons. 